\title{
Relative Potencies of the Somatostatin Analogs Octreotide, BIM- 23014, and RC-160 on the Inhibition of Hormone Release by Cultured Human Endocrine Tumor Cells and Normal Rat Anterior Pituitary Cells
}

\author{
L. J. HOFLAND, P. M. VAN KOETSVELD, M. WAAIJERS, \\ J. ZUYDERWIJK, AND S. W. J. LAMBERTS \\ Department of Medicine III, Erasmus University, Rotterdam, The Netherlands
}

\begin{abstract}
In the present study we investigated the effects of the somatostatin (SS) analogs octreotide, RC-160, and BIM-23014 on GH release by cultured cells of human $\mathrm{GH}$-secreting pituitary tumors, in normal rat anterior pituitary cells, and on gastrin release by cultured cells from a human gastrinoma.

In all GH-secreting adenomas and in rat anterior pituitary cells, RC- 160 was the most potent compound. RC- 160 significantly inhibited GH-, PRL, and/or $\alpha$-subunit release by human GH-secreting pituitary adenoma cells in concentrations as low as $10^{-12}-10^{-14} \mathrm{M}$, whereas at the same concentrations, octreotide and BIM-23014 did not inhibit or were significantly less effective in inhibiting GH release $(P<0.01, \mathrm{RC}-160$ us. octreotide and BIM-23014). In rat anterior pituitary cell cultures, the $\mathrm{IC}_{50}$ values for inhibition of $\mathrm{GH}$ release were, in rank order of potency, 0.1, 5.3, 47, 48, and 99 pM for RC-160, SS-14, BIM-23014, octreotide, and SS-28, respectively. Maximal inhibitory effects by the three analogs were the same in the human GH adenoma cell cultures and the rat anterior pituitary cell cultures $(-60 \%)$. On the basis of
\end{abstract}

these data, RC- 160 appears to be about 500 times more potent than octreotide and BIM-23014 in inhibiting GH release by rat anterior pituitary cells in vitro. Forskolin $(100 \mu \mathrm{M})$ as well as pretreatment of the cells with pertussis toxin significantly diminished the inhibitory effects of the three SS analogs and those of SS-14 and SS-28 to the same extent. The latter data suggest that octreotide, RC-160, and BIM23014 act mainly via a pertussis toxin-sensitive G-protein and an adenylyl cyclase-dependent mechanism. In the human gastrinoma culture, $\mathrm{KC}-160$ inhibited gastrin release significantly more than octreotide at $10^{-12}$ - and $10^{-14}-\mathrm{M}$ concentrations $(P<0.01)$.

In conclusion, the SS analogs octreotide, RC-160, and BIM-23014 may have significant different potencies of inhibition of hormone release in vitro, with $\mathrm{RC}-160$ being the most potent SS analog and octreotide and BIM-23014 having similar potencies. Depending on the pharmacokinetic properties of these three octapeptide SS analogs, these observations may have consequences for the medical therapy of patients with SS receptor-positive endocrine tumors. (Endocrinology 134: 301$306,1994)$
Sontin

OMATOSTATIN-14 (SS-14) is a tetradecapeptide that has inhibitory effects in a variety of endocrine tissues (1). The effects of SS (analogs) are mediated via high affinity membrane receptors belonging to the family of G-proteincoupled receptors. For clinical use, primarily in the treatment of $\mathrm{GH}$ hypersecretion in patients with $\mathrm{GH}$-secreting pituitary adenomas, several analogs of SS have been developed, which have a considerably longer biological half-life than SS-14 and do not cause a rebound $\mathrm{GH}$ hypersecretion as has been shown for SS-14 (2). Of these analogs, octreotide, BIM23014, and RC-160, only octreotide has obtained clinical importance so far (2). Bauer et al. (3) originally developed the highly potent octapeptide analog octreotide. Thereafter, several analogs related to octreotide were synthesized and tested for their biological activity by Cai et al. $(4,5)$. The latter investigators suggested that RC-160, one of their analogs, might be more specific for $\mathrm{GH}$ inhibition and had lower activity for inhibition of insulin and glucagon release in vivo. In addition, Liebow and co-workers (6) demonstrated an effect of RC-160, but not octreotide, on cell growth and

Received September 9, 1993.

Address all correspondence and requests for reprints to: Dr. L. J. Hofland, Department of Internal Medicine III, University Hospital Dijkzigt, 40 Doctor Molewaterplein, 3015 GD Rotterdam, The Netherlands. tyrosine phosphatase activity in the Mia-PaCa-2 human pancreatic tumor cell line. On the basis of recent data by other investigators, this discrepancy between the effects of $\mathrm{RC}-160$ and octreotide can be challenged, however $(7,8)$.

In vitro studies have shown differential binding of SS analogs in normal rat brain and adenohypophysis (9). In certain human tumors (breast cancer, ovarian cancer, and pancreatic cancer), differences in binding characteristics have been reported between octreotide and RC-160 (10).

The above data suggest that in normal tissues and in certain tumors, there may be differences in receptor binding characteristics and biological effects among the different SS analogs. However, there are as yet no in vitro studies that compare the effects of all three of the above-mentioned SS analogs in an established culture system and in primary cultures of SS receptor (SS-R)-positive endocrine tumors. In the present study, therefore, we compared the inhibitory effects of octreotide, BIM-23014, and RC-160 on GH release by cultured human GH-secreting pituitary adenoma cells and rat anterior pituitary cells and those of octreotide and RC-160 on gastrin release by a cultured human gastrinoma. In addition, we performed experiments dealing with the mechanism of action of inhibition of GH release by these SS analogs in the human GH adenoma and rat anterior pituitary cell cultures. 


\section{Materials and Methods}

\section{Cell culture.}

Tumor tissue from eight untreated acromegalic patients (patients 18) was obtained by transsphenoidal operation. Single cell suspensions of the adenoma tissue were prepared by enzymatic dissociation with dispase, as described in detail previously (11).

Tumor tissue from a patient with a gastrinoma was dissociated with collagenase (type I, Sigma Chemical Co., St. Louis, MO), as described previously (12).

Dispersed rat anterior pituitary cells were prepared by enzymatic dissociation of anterior pituitaries from female Wistar rats, weighing $180-200 \mathrm{~g}$, as previously described in detail (13). Animals were kept, treated, and cared for in accordance with the guidelines approved by the European Community on November 24, 1986.

The cells were plated at a density of $10^{5}$ cells/well in $1 \mathrm{ml}$ culture medium in multiwell plates (48 wells; Costar, Cambridge, MA). The human GH-secreting tumor cells and human gastrinoma cells were allowed to attach for 4 days at $37 \mathrm{C}$ in a $\mathrm{CO}_{2}$ incubator. Thereafter, the medium was changed, and 24- or 96-h incubations without or with test substances were carried out in quadruplicate. The rat anterior pituitary cells were allowed to attach for 4 days, after which the medium was changed. After another medium change on day 7 of culture, 4-h incubations without or with test substances were performed in quadruplicate. In the experiment with pertussis toxin (PT), the cells were preincubated for $2 \mathrm{~h}$ with PT before the 4-h incubation. At the end of the incubation, the medium was removed and centrifuged for $5 \mathrm{~min}$ at $600 \times 8$, and the supernatant was stored at $-20 \mathrm{C}$ until analysis. Forskolin and PT were used in concentrations of $100 \mu \mathrm{M}$ and $50 \mu \mathrm{g} /$ liter, respectively.

The culture medium in all experiments was Minimum Essential Medium with Earle's salts (MEM) supplemented with nonessential amino acids, sodium pyruvate $(1 \mathrm{mmol} / \mathrm{liter}), 10 \%$ fetal calf serum (FCS), penicillin $\left(1 \times 10^{5} \mathrm{U} /\right.$ liter $)$, fungizone $(0.5 \mathrm{mg} /$ liter $)$, L-glutamine ( $2 \mathrm{mmol} / \mathrm{liter}$ ), and sodium bicarbonate $(2.2 \mathrm{~g} / \mathrm{liter})$. The medium was adjusted to $\mathrm{pH} 7.4$ with $1 \mathrm{~mol} / \mathrm{liter} \mathrm{NaOH}$.

\section{Test substances}

PT and SS-14 were obtained from Sigma. Forskolin was obtained from Calbiochem Corp. (La Jolla, CA). BIM-23014 (SS tumor-inhibiting analog) and SS-28 were obtained from Bissendorf Biochemicals (Hannover, Germany). RC-160 was obtained from Peninsula (Belmont, CA). Octreotide was obtained from Sandoz (Basel, Switzerland).

The structures of octreotide, BIM-23014, and RC-160 are shown in Fig. 1.

\section{Hormone determinations}

Human GH and PRL concentrations in the culture medium were determined by immunoradiometric assays, as described previously (11). Glycoprotein $\alpha$-subunit concentrations in the medium were determined by a double antibody RIA, as described previously (11). Rat GH and rat PRL concentrations were determined by double antibody RIAs, using materials supplied by the NIDDK, as described in detail previously (13, 14).

Gastrin concentrations were determined by a double antibody RIA from Diagnostic Products Corp., as described previously (12).

Octreotide:

FIG. 1. Structures of the SS analogs octreotide, BIM-23014, and RC160. Arrows indicate differences from octreotide.

\section{Data analysis}

The statistical significance of the differences between mean values was determined using two-way analysis of variance. When significant overall effects were obtained by analysis of variance, multiple comparisons were made using the Newman Keuls test (15). Differences were considered significant when $P<0.05$. Each experiment with rat anterior pituitary cells is representative of at least two independent experiments.

\section{Results}

Effects of $S S$ analogs on $G H$-, $P R L$-, and $\alpha$-subunit release by cultured human $G H$-secreting pituitary adenoma cells

Table 1 shows the effects of octreotide, BIM-23014, and RC-160 on GH release by five cultures of human GHsecreting pituitary adenoma cells. In all cultures, $\mathrm{GH}$ release was significantly inhibited by the three analogs in a dosedependent fashion. Although the maximal inhibitory effects of the analogs were comparable in all cultures, there were considerable differences in the concentration range over which the analogs inhibited GH release. $\mathrm{RC}-160$ significantly inhibited $\mathrm{GH}$ release in concentrations up to $10^{-12} \mathrm{M}$ in four cultures (patients $1-4 ; P<0.01$ vs. control) and in a concentration up to $10^{-14} \mathrm{M}$ in one culture (patient 5), whereas at these concentrations, octreotide and BIM-23014 did not inhibit or were significantly less effective $(P<0.01 \mathrm{vs}$. effect of RC-160 in cultures of patients $1,2,3$, and $5 ; P<0.05$ vs. effect of $\mathrm{RC}-160$ in culture of patient 4) in inhibiting $\mathrm{GH}$ release in five cultures (patients 1-5) and four cultures (patients 2-5), respectively. Although in most cultures, a 24-h incubation with the SS analogs was performed (except in the culture of patient 3 , which represents a $96-\mathrm{h}$ incubation), we found a comparable difference in the potencies of $\mathrm{GH}$ inhibition between RC-160, octreotide, and BIM-23014 in cultures that were incubated for 4 or $96 \mathrm{~h}$ (data not shown), suggesting that the differences in the potencies between the analogs are not due to degradation of the drugs. In four cultures (patients 1, 3, 5, and 6) that secreted PRL and/or $\alpha$ subunit as well as $\mathrm{GH}$, the effects of octreotide and RC-160 on all three hormones were comparable. Again, RC-160 was significantly more potent than octreotide in inhibiting hormone release (GH, PRL, and $\alpha$-subunit). As an example, Fig. 2 shows that in the culture from patient 6 (not shown in Table 1), RC-160 was significantly more effective (in concentrations of $10^{-12}$ and $\left.10^{-14} \mathrm{M}\right)$ than octreotide $(P<0.01 v \mathrm{~s}$. effect of octreotide) in inhibiting GH, PRL, and $\alpha$-subunit release. Two other cultures (patients 7 and 8 ) that secreted GH and PRL simultaneously showed a low sensitivity of PRL release to the inhibitory effects of the somatostatin analogs, whereas GH release was significantly inhibited at the same time (Table 2). This demonstrates the specificity of the effects of the SS analogs. To study the involvement of a G-protein in the inhibitory effects of octreotide, BIM-23014, and RC-160, the cells from two cultures were pretreated with PT. In both cultures (patients 4 and 5), PT significantly reduced the inhibitory effect of the three SS analogs on GH release, although this was most evident in the culture from patient 5. This is shown in Table 3. 
TABLE 1. The effects of octreotide (OCTR), RC-160, and BIM-23014 on GH release by cultured human GH-secreting pituitary tumor cells

\begin{tabular}{|c|c|c|c|c|c|c|}
\hline Drug & $\begin{array}{c}\text { Conc. } \\
(\log \mathrm{M})\end{array}$ & $\begin{array}{c}\text { Patient } 1 \\
(24 \mathrm{~h})\end{array}$ & $\begin{array}{c}\text { Patient } 2 \\
(24 \mathrm{~h})\end{array}$ & $\begin{array}{c}\text { Patient } 3 \\
(96 \mathrm{~h})\end{array}$ & $\begin{array}{c}\text { Patient } 4 \\
(24 \mathrm{~h})\end{array}$ & $\begin{array}{l}\text { Patient } 5 \\
(24 \mathrm{~h})\end{array}$ \\
\hline OCTR & $\begin{array}{r}0 \\
-6 \\
-8 \\
-10 \\
-12 \\
-14\end{array}$ & $\begin{aligned} 1663 & \pm 47(100) \\
783 & \pm 49(47)^{a} \\
585 & \pm 25(35)^{a} \\
707 & \pm 27(43)^{a} \\
1303 & \pm 43(78)^{b, c} \\
& -\end{aligned}$ & $\begin{array}{c}8083 \pm 321(100) \\
2899 \pm 146(36)^{a} \\
2664 \pm 102(33)^{a} \\
3047 \pm 80(38)^{a} \\
7627 \pm 316(94)^{c} \\
\quad-\end{array}$ & $\begin{aligned} 1468 & \pm 35(100) \\
454 & \pm 5(31)^{a} \\
403 & \pm 10(27)^{a} \\
442 & \pm 8(30)^{a} \\
848 & \pm 44(58)^{a, c} \\
& -\end{aligned}$ & $\begin{array}{c}48 \pm 1(100) \\
- \\
35 \pm 2(73)^{a} \\
40 \pm 2(83)^{b, d} \\
48 \pm 2(100)^{d} \\
\quad-\end{array}$ & $\begin{array}{c}1149 \pm 29(100) \\
- \\
400 \pm 8(35)^{a} \\
415 \pm 5(36)^{a} \\
773 \pm 29(67)^{a, c} \\
1024 \pm 38(89)^{b, c}\end{array}$ \\
\hline $\mathrm{RC}-160$ & $\begin{array}{r}-6 \\
-8 \\
-10 \\
-12 \\
-14\end{array}$ & $\begin{array}{l}597 \pm 20(36)^{a} \\
553 \pm 25(33)^{a} \\
593 \pm 28(36)^{a} \\
810 \pm 62(49)^{a, d} \\
\quad-\end{array}$ & $\begin{aligned} 2267 & \pm 205(28)^{a} \\
2133 \pm & \pm 2(26)^{a} \\
2000 & \pm 29(25)^{a} \\
2967 & \pm 148(37)^{a, c} \\
& -\end{aligned}$ & $\begin{array}{c}527 \pm 12(36)^{a} \\
437 \pm 26(30)^{a} \\
413 \pm 15(28)^{a} \\
470 \pm 25(32)^{a} \\
-\end{array}$ & $\begin{array}{c}-\overline{2(69)^{a}} \\
33 \pm 2(77)^{a} \\
37 \pm 1(85)^{b} \\
41 \pm 2(\end{array}$ & $\begin{array}{l}\quad-\overline{19}(33)^{a} \\
377 \pm 15(35)^{a} \\
401 \pm 15(46)^{a, c} \\
523 \pm 40(46)^{a}\end{array}$ \\
\hline BIM-23014 & $\begin{array}{r}-6 \\
-8 \\
-10 \\
-12 \\
-14\end{array}$ & $\begin{array}{l}- \\
- \\
- \\
-\end{array}$ & $\begin{array}{l}2200 \pm 29(27)^{a} \\
2000 \pm 29(25)^{a} \\
2633 \pm 192(33)^{a} \\
4533 \pm 219(56)^{a, c} \\
\quad-\end{array}$ & $\begin{array}{l}427 \pm 12(29)^{a} \\
405 \pm 25(28)^{a} \\
465 \pm 5(32)^{a} \\
765 \pm 15(52)^{a, d} \\
\quad-\end{array}$ & 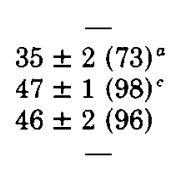 & $\begin{aligned} & - \\
520 & \pm 16(45)^{a} \\
642 & \pm 21(56)^{a, c} \\
825 & \pm 26(72)^{a, c} \\
1011 & \pm 34(88)^{b, c}\end{aligned}$ \\
\hline
\end{tabular}

$\mathrm{n}=4$ wells/treatment group. - , Not tested. Numbers in parentheses refer to the percentage of control release.

${ }^{a} P<0.01$ us. control.

${ }^{b} P<0.05$ us. control.

${ }^{c} P<0.01$ us. previous lower concentration of SS analog.

${ }^{d} P<0.05$ us. previous lower concentration of SS analog.

Effects of SS analogs on gastrin release by human gastrinoma cells

Figure 3 shows the effects of octreotide and RC-160 on gastrin release by cultured cells from a human gastrinoma. Both analogs significantly inhibited gastrin release in a dosedependent manner in concentrations as low as $10^{-14} \mathrm{M}$ (octreotide: $10^{-14}$ vs. $10^{-12} \mathrm{M}, P<0.05 ; 10^{-12}$ vs. $10^{-10} \mathrm{M}, P<$ 0.01; RC-160: $10^{-14}$ vs. $10^{-12} \mathrm{M}, P<0.05$ ). However, at $10^{-12}$ and $10^{-14} \mathrm{M}, \mathrm{RC}-160$ inhibited gastrin release significantly more than octreotide ( $P<0.01 \mathrm{vs}$. effect of octreotide). Again, the maximal inhibitory effects of octreotide and RC- 160 were similar. Insufficient cells were isolated from this tumor to study the effect of BIM-23014.

\section{Effects of SS analogs, SS-14, and SS-28 on GH release by cultured rat anterior pituitary cells}

In Fig. 4, the effects of octreotide, BIM-23014, RC-160, SS-14, and SS-28 on GH release by cultured rat anterior pituitary cells are shown. All SS (analogs) inhibited GH release maximally and to the same extent (by $\sim 60 \%$ ) at $10^{-8}$ M. However, the dose-response curve of RC-160 was significantly different from those of SS-14, BIM-23014, octreotide, and SS-28. Although RC-160 significantly inhibited GH release up to $10^{-14} \mathrm{M}$, no other somatostatin (analogs) significantly inhibited $\mathrm{GH}$ release at $10^{-12}$ or $10^{-14} \mathrm{M}$. $\mathrm{IC}_{5 n}$ values for inhibition of GH release were, in rank order of potency, $0.1,5.3,47,48$, and 99 pM for RC-160, SS-14, BIM-23014, octreotide, and SS-28, respectively. On the basis of these data, RC-160 appears to be about 500 times more potent than octreotide and BIM-23014 in inhibiting GH release by rat anterior pituitary cells in vitro. In 24- and 96-h incubations, this significant difference in the potency of inhibition of $\mathrm{GH}$ release among RC-160, octreotide, and BIM-23014 was still present (data not shown), but at the same time the $\mathrm{IC}_{50}$ value of inhibition of $\mathrm{GH}$ release by SS-14 was significantly lower (500 and $8700 \mathrm{pM}$, respectively), pointing to degradation of SS-14, but not of the SS analogs.

We also investigated the effect of a 2 -h preincubation with $50 \mu \mathrm{g} / \mathrm{liter}$ PT. Table 4 shows that pretreatment of the cells with PT significantly reduced the inhibitory effects of the three SS analogs, SS-14, and SS-28 on GH release. In addition, simultaneous exposure of the cells to a maximally active concentration of forskolin $(100 \mu \mathrm{M})$ resulted in significantly less inhibition of GH release by all SS analogs tested (Table 4; $P<0.01 v s$. percent effect on control untreated cells).

\section{Discussion}

The present study shows for the first time that the SS analogs octreotide, BIM-23014, and RC-160 have different potencies of inhibition of GH release by primary cultures of human GH-secreting pituitary tumor cells and normal rat anterior pituitary cells, and of inhibition of gastrin release by a primary culture of a human gastrinoma in vitro. In all cases, RC- 160 was clearly the most potent in its inhibitory action. Although the in vivo and in vitro effects of octreotide, BIM23014 , and RC-160 have been studied extensively, no studies have been performed so far comparing simultaneously the three SS analogs available for clinical use in primary cultures of human endocrine tumor cells and rat anterior pituitary cells.

Bauer et al. (3) originally developed a series of highly potent octapeptide analogs of SS-14, of which octreotide was the most active. Thereafter, several other analogs, related to octreotide, were synthesized and tested for their biological activity by Cai and co-workers $(4,5)$. Cai et al. found that substitution of Phe and Thr by Tyr and Val, respectively, at positions 3 and 6 resulted in a much higher potency for 

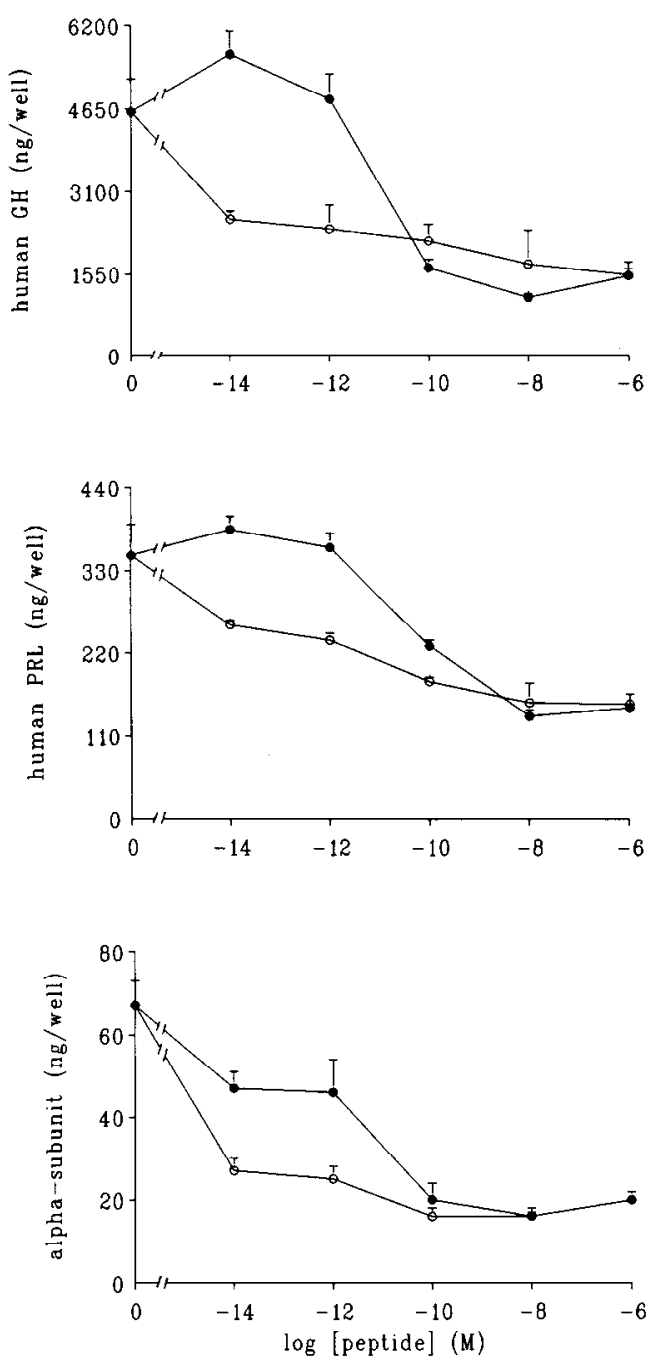

FIG. 2. Dose-response relationship of the effects of the SS analogs octreotide and RC- 160 on hormone release by a cultured mixed GH-, PRL-, and $\alpha$-subunit-secreting human pituitary adenoma (patient 6). Cells $\left(10^{5}\right)$ were cultured for 4 days in MEM-10\% FCS. On day 4 of culture, the medium was changed, and a $24-\mathrm{h}$ incubation without or with octreotide $(-)$ and $\mathrm{RC}-160(\mathrm{O})$ was performed in quadruplicate. Values are the mean $\pm \mathrm{SE}$.

inhibition of $\mathrm{GH}$ secretion, but lower activity for inhibition of insulin and glucagon release in vivo in rats. They also suggested that replacing Thr at position 8 by Trp may result in increased receptor affinity. This suggests that the $\mathrm{Tyr}^{3} /$ $\mathrm{Val}^{6}$-containing series of analogs might be more specific for $\mathrm{GH}$ inhibition, and there may be selectivities in the biological actions of SS octapeptide analogs. Both RC-160 and BIM23014 are $\mathrm{Tyr}^{3} / \mathrm{Val}^{6}$-containing analogs, whereas $\mathrm{RC}-160$ also has $\operatorname{Trp}$ at position 8 . On the basis of the results from our present study, we can confirm this high potency of inhibition of GH secretion by RC-160 in cultures of human $\mathrm{GH}$-secreting pituitary adenomas and in one culture of a human gastrinoma. In $\mathrm{GH}$-secreting pituitary adenomas, octreotide and BIM-23014 inhibited GH release to the same extent, whereas RC-160 was clearly the most active compound. In cultured rat anterior pituitary cells, RC-160 was about 500 times more potent than octreotide and BIM-23014.
TABLE 2. Effects of SS analogs on GH and PRL release by cultured GH-secreting pituitary adenoma cells

\begin{tabular}{clcl}
\hline $\begin{array}{c}\text { Patient } \\
\text { no. }\end{array}$ & \multicolumn{1}{c}{ Treatment } & $\begin{array}{c}\text { GH } \\
(\mu \mathrm{g} / \text { liter })\end{array}$ & $\begin{array}{c}\text { PRL } \\
(\mu \mathrm{g} / \text { liter })\end{array}$ \\
\hline 7 & Control & $1583 \pm 75$ & $165 \pm 3$ \\
& Octr $\left(10^{-8} \mathrm{M}\right)$ & $808 \pm 51(51)^{a}$ & $177 \pm 6(107)$ \\
& BIM $\left(10^{-8} \mathrm{M}\right)$ & $950 \pm 33(60)^{a}$ & $190 \pm 6(115)$ \\
& RC $\left(10^{-8} \mathrm{M}\right)$ & $938 \pm 17(59)^{a}$ & $157 \pm 7(95)$ \\
& & & \\
8 & Control & $269 \pm 17$ & $51 \pm 3$ \\
& Octr $\left(10^{-10} \mathrm{M}\right)$ & $138 \pm 4(51)^{a}$ & $43 \pm 2(84)^{b}$ \\
& RC $\left(10^{-10} \mathrm{M}\right)$ & $138 \pm 6(51)^{a}$ & $43 \pm 2(84)^{b}$ \\
\hline
\end{tabular}

$\mathrm{n}=4 \mathrm{wells} /$ treatment. The incubation times were 24 and $96 \mathrm{~h}$ for cultures from patients 7 and 8, respectively. Octr, Octreotide; BIM, BIM-23014; RC, RC-160. Values are the mean \pm SE. Numbers in parentheses refer to the percentages of control values.

${ }^{a} P<0.01$ vs. control cells.

${ }^{b} P<0.05$ vs. control cells.

'TABLE' 3. Effects of pretreatment with PT on the inhibitory effects of octreotide (Octr), RC-160 (RC), and BIM-23014 (BIM) on $\mathrm{GH}$ release by cultured human $\mathrm{GH}$-secreting pituitary adenoma cells

\begin{tabular}{clcc}
\hline \multirow{2}{*}{$\begin{array}{c}\text { Patient } \\
\text { no. }\end{array}$} & Treatment & \multicolumn{2}{c}{ GH release (ng/well) } \\
\cline { 3 - 4 } & & $-\mathrm{PT}$ & $+\mathrm{PT}$ \\
\hline \multirow{2}{*}{4} & Control & $48 \pm 1$ & $59 \pm 1^{a}$ \\
& Octr $\left(10^{-8} \mathrm{M}\right)$ & $35 \pm 2(73)^{b}$ & $49 \pm 1(83)^{b, c}$ \\
& BIM $\left(10^{-8} \mathrm{M}\right)$ & $35 \pm 2(73)^{b}$ & $49 \pm 1(83)^{b, c}$ \\
& RC $\left(10^{-8} \mathrm{M}\right)$ & $33 \pm 2(69)^{b}$ & $48 \pm 1(81)^{b, c}$ \\
& & & \\
5 & Control & $1149 \pm 29$ & $1641 \pm 59^{a}$ \\
& Octr $\left(10^{-9} \mathrm{M}\right)$ & $398 \pm 7(35)^{b}$ & $1452 \pm 47(88)^{b, d}$ \\
& BIM $\left(10^{-9} \mathrm{M}\right)$ & $608 \pm 6(53)^{b}$ & $1521 \pm 59(93)^{d, e}$ \\
& RC $\left(10^{-9} \mathrm{M}\right)$ & $388 \pm 12(34)^{b}$ & $1284 \pm 22(78)^{b, d}$ \\
\hline
\end{tabular}

$\mathrm{n}=4 \mathrm{wells} /$ treatment. Values are the mean $\pm \mathrm{sE}$. The incubation time was $24 \mathrm{~h}$ for cultures from patients 4 and 5 ; before this 24-h incubation, the cells were preincubated for $2 \mathrm{~h}$ with $50 \mu \mathrm{g} / \mathrm{liter}$ PT. Numbers in parentheses refer to the percentages of control values.

${ }^{a} P<0.01$ vs. control without $\mathrm{PT}$.

${ }^{b} P<0.01$ vs. control cells.

${ }^{c} P<0.05$ vs. effect of SS analog on cells without PT.

${ }^{d} P<0.01$ us. effect of SS analog on cells without PT.

${ }^{e} P<0.05$ vs. control cells.

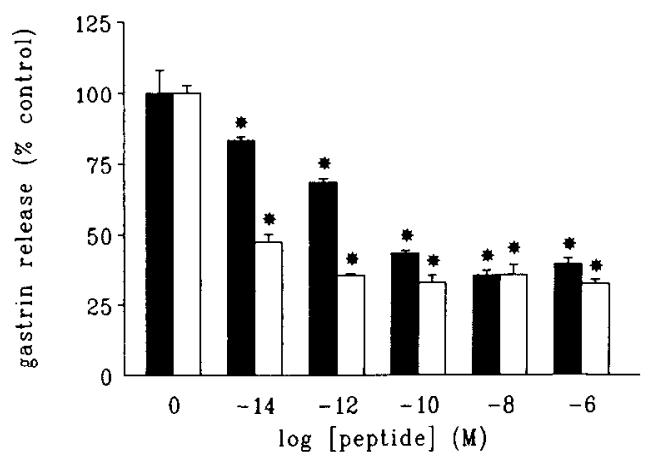

FIG. 3. Dose-response relationship of the effect of the SS analogs octreotide and RC-160 on gastrin release by cultured cells of a human gastrinoma. Cells $\left(10^{5}\right)$ were cultured for 4 days in MEM-10\% FCS. On day 4 of culture, the medium was changed, and a $24-h$ incubation without or with octreotide $(\square)$ and RC-160 ( $\square$ ) was performed in quadruplicate. Values are the mean $\pm \mathrm{SE}$; basal gastrin release values are $13 \pm 1$ and $15 \pm 0.5 \mathrm{ng} /$ well, respectively. ${ }^{*}, P<0.01 \mathrm{vs}$. control. 


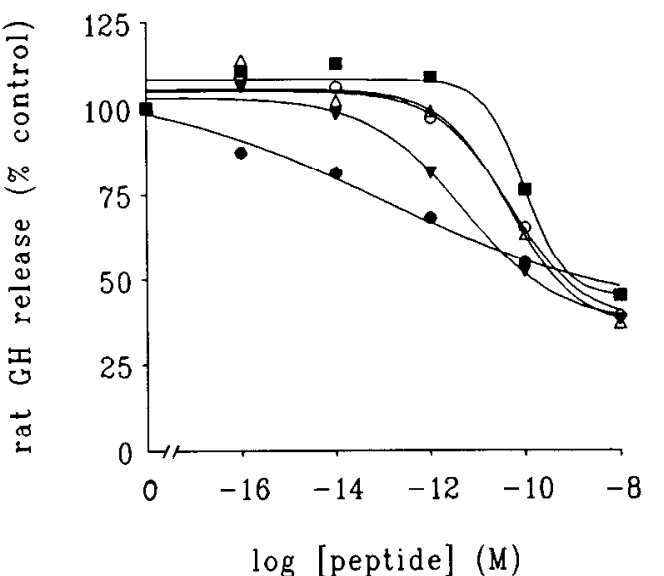

FIG. 4. Dose-response relationship of the effects of SS and SS analogs on $\mathrm{GH}$ release by cultured normal rat anterior pituitary cells. On day 7 of culture, 4-h incubations were performed in quadruplicate. Values are expressed us a percentage of control $\mathrm{GH}$ release and represent the

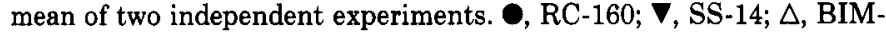
23014; O, octreotide; $\square$, SS-28.

TABLE 4. Effects of forskolin and PT on the inhibitory effects of SS and SS analogs on GH secretion by cultured rat anterior pituitary cells

\begin{tabular}{lccc}
\hline \multicolumn{1}{c}{ Treatment } & Control & $\begin{array}{c}\text { Forskolin } \\
(100 \mu \mathrm{M})\end{array}$ & $\begin{array}{c}\text { PT } \\
(50 \mu \mathrm{g} / \text { liter })\end{array}$ \\
\hline Control & $100 \pm 4$ & $100 \pm 6$ & $100 \pm 2$ \\
Octr $\left(10^{-8} \mathrm{M}\right)$ & $41 \pm 3^{a}$ & $79 \pm 1^{a, b}$ & $81 \pm 1^{a, b}$ \\
RC-160 $\left(10^{-8} \mathrm{M}\right)$ & $44 \pm 3^{a}$ & $78 \pm 2^{a, b}$ & $83 \pm 2^{a, b}$ \\
BIM $\left(10^{-8} \mathrm{M}\right)$ & $43 \pm 2^{a}$ & $69 \pm 3^{a, b}$ & $92 \pm 2^{a, b}$ \\
SS-14 $\left(10^{-8} \mathrm{M}\right)$ & $41 \pm 2^{a}$ & $68 \pm 3^{a, b}$ & $76 \pm 2^{a, b}$ \\
SS-28 $\left(10^{-8} \mathrm{M}\right)$ & $31 \pm 3^{a}$ & $70 \pm 4^{a, b}$ & $74 \pm 4^{a, b}$ \\
\hline
\end{tabular}

Rat anterior pituitary cells were cultured for 7 days. On day 7 of culture, 4-h incubations without or with test substances were performed in quadruplicate. Before this 4 -h incubation, a 2-h preincubation with PT was performed. All effects are expressed as a percentage of the respective control value. Forskolin stimulated basal GH release to 345 $\pm 8 \%$ of control GH release, and PT slightly stimulated GH release to $117 \pm 5 \%$. $n=4$ wells/treatment group. Values are the mean \pm SE. Octr, Octreotide; BIM, BIM-23014.

${ }^{a} P<0.01$ vs. control.

${ }^{b} P<0.01$ vs. effect of SS (analog) in control cells.

On the basis of many studies it has become evident that the SS-R shows both pharmacological and molecular heterogeneity, either within a particular SS-R-positive organ or between SS-R-positive organs (i.e. brain, pituitary, adrenal, and exocrine pancreas). With respect to the anterior pituitary gland, Patel et al. have shown, by cross-linking of SS-R proteins and using different SS-R ligands, the presence of three receptor proteins of 80,58 , and 27 kilodaltons in size $(1,16)$, whereas other investigators reported two subtypes of the receptor in the rat anterior pituitary gland which differ in size (82 and 94 kilodaltons) and sensitivity to estrogen regulation (17). Recently, five different SS-R genes have been cloned. Cultured cell lines that stably express these five recombinant SS-R genes have been established, and it is clear that these different genes are encoding for receptor proteins with approximately the same affinity for SS-14 and SS-28, but different affinities for the SS analogs octreotide and MK678 , demonstrating that there is a molecular basis for the observed pharmacological and molecular heterogeneities of SS-R (18). Finally, in a very small subgroup of human pituitary adenomas, Reubi et al. (19) found, using autoradiographic studies, SS-R with low affinity to octreotide and high affinity to SS-28, whereas the vast majority of the tumors showed high affinity to both ligands. At this moment we cannot exclude that the difference between the $\mathrm{GH}$ inhibitory effects of the SS analogs is caused by interaction with different SS-R subtypes. Comparative binding studies using the three SS analogs in cultured cell lines that stably express the somatostatin receptor subtypes might help to resolve this question. There are, however, several lines of evidence that argue against this hypothesis. First, we found comparable differences among the effects of octreotide, RC160 , and BIM-23014 in all GH-secreting pituitary adenomas, whereas SS-R with a low affinity for octreotide are found in only a small subgroup of the adenomas. Secondly, the maximal inhibitory effects of octreotide, RC-160, and BIM-23014 were the same in three culture systems we used in our study. Thirdly, a maximal concentration of forskolin as well as pretreatment of the cells with PT significantly reduced the inhibitory effects of the three SS analogs, SS-14, and SS-28 to the same extent. In our experiments we performed a $2-\mathrm{h}$ pretreatment with PT. A longer preincubation with PT might have completely blocked the inhibitory effect of the SS analogs. The latter data suggest that octreotide, RC-160, and BIM-23014 all act mainly via a PT-sensitive G-protein and adenylyl cyclase-dependent mechanism. Therefore, we suggest that the major differences among octreotide, BIM-23014, and RC-160 in their hormone release inhibitory effects are caused by differences in affinity for the same receptor.

Although it is clear from our study that in all GH-secreting pituitary adenomas and in the gastrinoma studied, RC-160 is clearly more potent in its inhibitory action on hormone release, the clinical significance of this finding has yet to be established. In previous studies comparing receptor binding characteristics with bioactivity in vivo and in vitro, several investigators have shown that with certain SS analogs there may be a dissociation between binding characteristics and bioactivity $(9,20,21)$. The dissociation constant of the SS-R is approximately $1 \mathrm{nM}(22,23)$. In normal men, sc administration of $100 \mu \mathrm{g}$ octreotide was reported to result after 30$60 \mathrm{~min}$ in circulating octreotide levels of between 1.6-2.5 nM (24). In this nanomolar concentration range, however, we did not observe differences in the $\mathrm{GH}$ and gastrin release inhibitory effects among the three SS analogs studied. Only at significantly lower concentrations (picomolar range) did the differences between the analogs became evident. If this difference in the potency of inhibition of hormone release among RC-160, octreotide, and BIM-23014 is related to a difference among these SS analogs in affinity for the SS-R, it may have implications in the treatment of those tumors that have low affinity for octreotide but high affinity for SS14 and SS-28, as has been reported in a subgroup of insulinomas, medullary thyroid carcinomas, carcinoids, and a small subgroup of GH-secreting pituitary adenomas (25). Moreover, Srkalovic et al. (10) previously showed that RC160 had a significant higher affinity for SS-14-binding sites, 
compared to that of octreotide, in human ovarian, breast, and pancreatic cancers.

In conclusion, this study shows for the first time in primary cultures of human $\mathrm{GH}$-secreting pituitary tumor cells and human gastrinoma cells that three SS analogs, available for clinical use, i.e. octreotide, RC-160, and BIM-23014, may have significant different potencies of inhibition of hormone release in vitro, with $\mathrm{RC}-160$ being the most potent $\mathrm{SS}$ analog. It is suggested that in $\mathrm{GH}$ (adenoma) cells these analogs all act mainly via a PT-sensitive G-protein and adenylyl cyclasedependent mechanism. Depending on the pharmacokinetic properties of these three octapeptide SS analogs, these observations may have consequences for the medical therapy of patients with SS-R-positive endocrine tumors.

\section{References}

1. Patel YC, Murthy KK, Escher EE, Banville D, Spiess J, Srikant CB 1990 Mechanism of action of somatostatin: an overview of receptor function, studies of the molecular characterization, purification of somatostatin receptor proteins. In: Patel YC, Tannenbaum GS (eds) Metabolism 1990. W. B. Saunders Co., Philadelphia, vol 39(Suppl 2):63-69

2. Lamberts SWJ 1988 The role of somatostatin in the regulation of anterior pituitary hormone secretion and the use of its analogs in the treatment of human pituitary tumors. Endocr Rev 9:417-436

3. Bauer W, Briner U, Doepfner W, Haller R, Huguenin R, Marbach P, Petcher TJ, Pless J 1982 SMS 201-995: a very potent and selective octapeptide analogue of somatostatin with prolonged action. Life Sci 31:1133-1140

4. Cai R-Z, Szoke B, Lu R, Fu D, Redding TW, Schally AV 1986 Synthesis and biological activity of highly potent octapeptide analogs of somatostatin. Proc Natl Acad Sci USA 83:1896-1900

5. Cai R-Z, Karashima T, Guoth J, Szoke B, Olsen D, Schally AV 1987 Superactive octapeptide somatostatin analogues containing tryptophan at position 1. Proc Natl Acad Sci USA 84:2502-2506

6. Liebow C, Reilly C, Serrano M, Schally AV 1989 Somatostatin analogues inhibit growth of pancreatic cancer by stimulating tyrosin phosphatase. Proc Natl Acad Sci USA 86:2003-2007

7. Gillespie J, Poston GJ, Schachter M, Guillou PJ 1992 Human pancreatic cancer cell lines do not express receptors for somatostatin. Br J Cancer 66:483-487

8. Colas B, Cambillau C, Buscail L, Zeggari M, Esteve J-P, Lautre V, Thomas F, Vaysse N, Susini C 1992 Stimulation of a membrane tyrosine phosphatase activity by somatostatin analogues in rat pancreatic acinar cells. Eur J Biochem 207:1017-1024

9. Heiman ML, Murphy WA, Coy DH 1987 Differential binding of somatostatin agonists to somatostatin receptors in brain and adenohypophysis. Neuroendocrinology 45:429-436
10. Srkalovic G, Cai R-Z, Schally AV 1990 Evaluation of receptors for somatostatin in various tumors using different analogs. J Clin Endocrinol Metab 70:661-669

11. Hofland LJ, van Koetsveld PM, Verleun TM, Lamberts SWJ 1989 Glycoprotein alpha-subunit and prolactin release by cultured pituitary adenoma cells from acromegalic patients: correlation with $\mathrm{GH}$ release. Clin Endocrinol (Oxf) 30:601-611

12. Lamberts SWJ, Hofland LJ, van Koetsveld PM, Reubi J-C, Bruining HA, Bakker WH, Krenning EP 1990 Parallel in vivo and in vitro detection of functional somatostatin receptors in human endocrine pancreatic tumors: consequences with regard to diagnosis, localization, and therapy. J Clin Endocrinol Metab 71:566-574

13. Oosterom R, Verleun T, Lamberts SWJ 1983 Basal and dopamineinhibited prolactin secretion by rat anterior pituitary cells: effects of culture conditions. Mol Cell Endocrinol 29:197-212

14. Oosterom R, Verleun T, Zuyderwijk J, Lamberts SWJ 1983 Growth hormone secretion by cultured rat anterior pituitary cells. Effects of culture conditions and dexamethasone. Endocrinology 113:735-746

15. Snedecor GW, Cochran WG 1980 Statistical Methods, ed 7. Iowa State University Press, Ames, pp 235-237

16. Srikant CB, Murthy KK, Escher EE, Patel YC 1992 Photoaffinity labeling of the somatostatin receptor: identification of molecular subtypes. Endocrinology 130:2937-2946

17. Kimura N, Hayafuji C, Kimura N 1989 Characterization of $17 \beta$ estradiol-dependent and -independent somatostatin receptor subtypes in rat anterior pituitary. J Biol Chem 264:7033-7040

18. Bell GI, Reisine T 1993 Molecular biology of somatostatin receptors. Trends Neurosci 16:34-38

19. Reubi J-C, Landolt AM 1989 The growth hormone responses to octreotide in acromegaly correlate with adenoma somatostatin receptor status. J Clin Endocrinol Metab 68:844-850

20. Murphy WA, Heiman ML, Lance VA, Mezo I, Coy DH 1985 Octapeptide analogs of somatostatin exhibiting greatly enhanced in vivo and in vitro inhibition of growth hormone secretion in the rat. Biochem Biophys Res Commun 132:922-928

21. Reubi J-C, Perrin M, Rivier J, Vale W 1982 Pituitary somatostatin receptors: dissociation at the pituitary level of receptor affinity and biological activity for selective somatostatin analogs. Regul Peptides 4:141-146

22. Reubi JC, Landolt AM 1984 High density of somatostatin receptors in pituitary tumors from acromegalic patients. J Clin Endocrinol Metab 59:1148-1151

23. Moyse E, Le Dafniet $M$, Epelbaum J, Pagesy $P$, Peillon F, Kordon C, Enjalbert A 1985 Somatostatin receptors in human growth hormone and prolactin-secreting pituitary adenomas. J Clin Endocrinol Metab 61:98-103

24. del Pozo E, Neufeld M, Schlutter K, Tortosa F, Clarenbach $P$, Bieder E, Wendel L, Nuesch E, Marbach P, Cramer H, Kerp L 1986 Endocrine profile of a long acting somatostatin derivate SMS 201-995. Study in normal volunteers following subcutaneous administration. Acta Endocrinol (Copenh) 111:433-439

25. Lamberts SWJ 1991 The role of somatostatin and its analogs in the diagnosis and treatment of tumors. Endocr Rev 12:450-482 